\title{
動作時間を考慮した消費エネルギー最少規範による マニピュレータの軌道計画
}

\author{
加島 正* 石 動 善 久*
}

\author{
Trajectory Planning of Manipulators Based on a Minimum-Energy Criterion \\ and Operating Time
}

Tadashi Kashima* and Yoshihisa Isurugi*

\begin{abstract}
Manipulators are equipped with several joints and it is possible to operate along any given trajectories. This flexibility is essential advantages and valuable studies are conducted for trajectory planning to effectively control manipulators. However, manipulators belong to a class of complex nonlinear dynamic systems and the application of trajectory planning leads to substantial difficulties. Therefore, various methods are proposed to solve optimal problems by adding or neglecting adequate constraints. However, they do not seem to offer generalized trajectory formation methods.

This paper discusses trajectory planning of point-to-point operations under condition that only an initial and a final states are given. Performance criterion is defined by consumed energy dissipated in operations and motor torque limit is considered. Mathematical formulation to calculate optimal trajectories is proposed and simulation is conducted for a 2 degrees of freedom manipulator. Amount of energy dissipation is discussed in relation with optimal and various operating time for typical manipulator movements. Besides, merit of trajectory planning based on a minimum-energy criterion and operating time is stated. Finally, characteristics of energy consumption in human arm movements is discussed and formulated trajectories are verified that they show similar features with human arm trajectories in relatively fast movements.
\end{abstract}

Key Words: Robot Manipulator, Optimal Control, Minimum-Energy Criterion, Trajectory Planning

\section{1.はじめに}

マニピュレータは複数の関節を有しており, 構造的にはハン ドを初期点から目標点まで移動させるといった基本的な動作で は無数の経路および速度パターンで運動を制御することが可能 である。このようなマニピュレータがもつ利点を有効に活用し て高度な制御能力を付加するために，消費エネルギーや動作時 間などの最少化を目指した軌道計画に関する研究が広く展開さ れている.

マニピュレータは非線形性をもつ多自由度系の機構であり， 最適軌道を解析的に得ることは極めて困難である。このような 軌道計画問題に対して関節軌道を適当な関数で近似して最適軌 道を求める手法 [1][2]，あるいはマニピュレータの空間経路が拘 束される条件のもとで最適な関節速度を求める手法 [3] [5] が 提案されている。しかし，これらの手法は 2 点間の移動動作に 対する一般的な最適解を与える手法とは言い難く検討の余地が 残されていた。このように適切な拘束を付加する手法とは別に， マニピュレータの初期姿勢，目標姿勢および動作時間のみが条

原稿受付 1996 年 7 月 26 日

*北海道大学工学部

*Faculty of Engineering, Hokkaido University
件として与えられたときの軌道計画の手法が報告されている． 評価関数は関節トルクの 2 乗の時間積分 [6] および消費エネル ギー [7]であり，最適制御問題の定式化の結果として㷌着する 2 点境界値問題を数值解法によって解いている。しかし，これ らは指定された動作時間での最適軌道の生成手法を示すもので あり，動作時間を自由とした条件のもとでの軌道計画の手法は 示されていない。また，モータのトルク制限が考虑されておら ず，大きなトルクを必要とする短い動作時間でマニピュレータ を作動させる場合の最適軌道の生成など考虑すべき問題を残し ていた。このほか，動作時間一燃料 [8] や動作時間 [9] を評価関 数として最適軌道を求めた報告があるが，いずれも一般的な軌 道計画問題の解法を与えるには至っていない。

一方，このようなマニピュレータの工学的に明快な利点を追 求する軌道計画とは異なり，ヒトの上肢運動における軌道を生 成しようとする研究成果 [10][11] が報告されている．このよう な観点から筆者らは運動中に生体内で消費するエネルギー要素 で構成する評価関数を用いて軌道を生成し，これがヒトの上肢 運動における軌道とよく一致することを示した [12]. しかし， このようなヒトの軌道の生成手法をマニピュレータの軌道計画 に適応するにはマニピュレータが必然的に持つモータトルクの 制約，あるいはここで用いた制御規範を最少にすることによる 
工学的な利点を明らかにするなど検討すべき問題が残されて いた.

本研究ではマニピュレータの初期姿勢と目標姿勢が与えられ たときの移動動作における軌道計画問題を論ずる. 評価関数は 実用機において常にその抑制が期待されている動作中に消費す るエネルギーで定義し，さらに駆動系の制約としてモータのト ルク制限を考虑する。この制約のもとで最適軌道を求めるため の定式化とアルゴリズムを動作時間が条件で与えられる場合と 自由な場合のそれぞれについて示す，次に，垂直面内で運動す る 2 自由度のシミュレーションモデルを用いて動作時間とその ときの消費エネルギーの関係を求め, 動作時間を変数とする軌 道計画の利点を示す．また，目標姿勢を変化させることでハン ドの移動距離と最適動作時間の関係および動作時間を考慮した 最適軌道の特性を明らかにする。最後に，ヒトとマニピュレー 夕のエネルギー消費特性を検討するとともに時間を考虑した消 費エネルギー最少の軌道計画手法を用いることで比較的速い動 作のヒトの上肢運動の軌道が生成できることを示す.

\section{2. 軌道計画問題の定式化と解法}

\section{1 運動方程式}

マニピュレータの運動方程式は, $n$ 次元関節角ベクトルを $\boldsymbol{\theta}$ とすれば次式で与えられる。

$$
\boldsymbol{M}(\boldsymbol{\theta}) \ddot{\theta}+\boldsymbol{h}(\boldsymbol{\theta}, \dot{\theta})+\boldsymbol{g}(\boldsymbol{\theta})+\boldsymbol{C} \dot{\theta}=u
$$

ここで, $\boldsymbol{M}(\boldsymbol{\theta})$ は $n \times n$ 慣性行列, そして $\boldsymbol{h}(\boldsymbol{\theta}, \dot{\boldsymbol{\theta}})$ と $\boldsymbol{g}(\boldsymbol{\theta})$ は $n$ 次のベクトルでありそれぞれコリオリ・遠心力および重力を 表す．また, $\boldsymbol{C}$ は各関節の粘性摩擦係数を要素にもつ対角行列 であり, $\boldsymbol{u}$ は $n$ 次の関節駆動トルクベクトルである。式 (1) で状態変数べクトルを $\boldsymbol{x}=\left(\boldsymbol{x}_{p}^{T}, \boldsymbol{x}_{v}^{T}\right)^{T}=\left(\boldsymbol{\theta}^{T}, \dot{\theta}^{T}\right)^{T}$ と定義す ると,

$$
\dot{x}=a(x)+B(x) u
$$

ここで,

$$
\begin{aligned}
& \boldsymbol{a}(\boldsymbol{x})=\left[\begin{array}{l}
\boldsymbol{x}_{v} \\
-\boldsymbol{M}^{-1}\left(\boldsymbol{x}_{p}\right)\left(\boldsymbol{h}(\boldsymbol{x})+\boldsymbol{g}\left(\boldsymbol{x}_{p}\right)+\boldsymbol{C} \boldsymbol{x}_{v}\right)
\end{array}\right] \\
& \boldsymbol{B}(\boldsymbol{x})=\left[\begin{array}{l}
\mathbf{0} \\
\boldsymbol{M}^{-1}\left(\boldsymbol{x}_{p}\right)
\end{array}\right]
\end{aligned}
$$

となり, $2 \times n$ 次の非線形状態方程式で表現することができる.

\section{2 評価関数}

マニピュレータを動作する過程で必要なエネルギーのうち主 要なものは初期姿势と目標姿勢の位置エネルギーの差分に相当 するエネルギー，関節駆動モータのジュール熱およびマニピュ レー夕摺動部における粘性摩擦により散逸するエネルギーであ る.このうち, 軌道計画においては初期姿勢と目標姿勢をあら かじめ規定するのでマニピュレータの位置エネルギーを変化さ せるためのエネルギーは軌道に依存せず一定となる。したがっ て, 本研究では消費エネルギーを規範とする評価関数を運動中 に散逸するジュール熱と粘性摩擦によるエネルギーを用いて，

$$
\boldsymbol{J}=\int_{t_{0}}^{t_{f}}\left(i^{T} \boldsymbol{R} i+\boldsymbol{x}_{v}^{T} \boldsymbol{C} \boldsymbol{x}_{v}\right) d t
$$

と定義する.ここで $t_{0}$ と $t_{f}$ はそれぞれ動作の開始と終 了時間， $i$ は $n$ 次のモー夕電流べクトルである。また， $\boldsymbol{R}=\operatorname{diag}\left(r_{1}, \cdots, r_{n}\right)$ と $\boldsymbol{C}=\operatorname{diag}\left(c_{1}, \cdots, c_{n}\right)$ はそれぞれ モー夕電機子抵抗およびマニピュレー夕摺動部の粘性摩擦係数 の行列である。モータのトルク定数を $k_{i}(i=1, \cdots, n)$, また 減速比を $p_{i}(i=1, \cdots, n)$ とすると,

$$
\boldsymbol{J}=\int_{t_{0}}^{t_{f}}\left(\boldsymbol{u}^{T} \boldsymbol{T} \boldsymbol{u}+\boldsymbol{x}_{v}^{T} \boldsymbol{C} \boldsymbol{x}_{v}\right) d t
$$

を得る。ここで, $\boldsymbol{T}=\operatorname{diag}\left(r_{1} p_{1}^{2} k_{1}^{-2}, \cdots, r_{n} p_{n}^{2} k_{n}^{-2}\right)$ である.

\section{3 最適軌道}

マニピュレータを指定された初期姿勢から目標姿势に移動す るとき, 式 (2) の運動方程式の拘束のもとで式 (4) の評価関 数を最少にするのが最適軌道である。この軌道を求めるために， 随伴変数べクトル $\boldsymbol{\lambda}=\left(\lambda_{1}, \cdots, \lambda_{n}\right)^{T}$ を導入し, ハミルトン関 数を,

$$
H(x, u, \lambda)=u^{T} \boldsymbol{T} u+x_{v}^{T} C x_{v}+\lambda^{T} f(x, u)
$$

ここで, $\boldsymbol{f}(\boldsymbol{x}, \boldsymbol{u})=\boldsymbol{a}(\boldsymbol{x})+\boldsymbol{B}(\boldsymbol{x}) \boldsymbol{u}$ と定義する. 次に，式 （6）に示すモータのトルク $\tau_{i}(i=1, \cdots, n)$ の制限を考虑する.

$$
\tau_{i \min } \leq \tau_{i} \leq \tau_{i \max } \quad(i=1, \cdots, n)
$$

ここで, モータの減速比を考慮するとマニピュレータの駆動卜 ルク $u_{i}(i=1, \cdots, n)$ の範囲は,

$$
\frac{\tau_{i \min }}{p_{i}} \leq u_{i} \leq \frac{\tau_{i \max }}{p_{i}} \quad(i=1, \cdots, n)
$$

となる.このように入力が制限される場合, ポントリャーギン の原理によれば最適な入力 $\boldsymbol{u}$ はハミルトン関数 $H$ を最少にす る.つまり, 式（5）を最少にする最適入力 $\boldsymbol{u}$ のもとで,

$$
\dot{\lambda}^{T}=-\frac{\partial H}{\partial \boldsymbol{x}}
$$

および

$$
\dot{\boldsymbol{x}}=\boldsymbol{f}(\boldsymbol{x}, \boldsymbol{u})
$$

を満足するのが最適軌道である。

式（8）と式（9）はそれぞれ $2 \times n$ 個の 1 階非線形微分方程 式である．軌道計画においては動作前後でのマニピュレータの 状態量が規定されるので,これは 2 点境界值問題に帰着される. 本研究では動作時間を条件で与える場合と自由とする場合のそ れぞれについて解法アルゴリズムを示す。

（1）動作時間が条件で与えられる場合

$2 \times n$ 個の微分方程式を数値解法により解くには条件で与え られる状態量 $\boldsymbol{x}\left(t_{0}\right)$ のほかに $\boldsymbol{\lambda}$ の初期値が必要である。した がって, 任意の初期値 $\boldsymbol{\lambda}_{t_{0}}$ を与えて計算するが, 動作終了時点 での状態量は条件で与えられた $\boldsymbol{x}_{t_{f}}$ とは異なる。したがって， $\boldsymbol{\lambda}_{t_{0}}$ を適宜変化させて $\boldsymbol{x}_{t_{f}}$ が $\boldsymbol{x}\left(t_{f}\right)$ と一致する初期值を探索 しなければならない。この探索には次式の Transition-MatrixAlgorithm [13] を用いる。

$$
\boldsymbol{\lambda}_{t_{0}}^{\text {new }}=\boldsymbol{\lambda}_{t_{0}}^{\text {old }}-\varepsilon\left[\frac{\partial \boldsymbol{x}_{t_{f}}}{\partial \boldsymbol{\lambda}_{t_{0}}}\right]^{-1}\left(\boldsymbol{x}_{t_{f}}-\boldsymbol{x}\left(t_{f}\right)\right)
$$

ここで, $\varepsilon$ は任意の係数であり, 解の収束性に応じ $0<\varepsilon \leq 1$ 
の範囲で適宜設定する. また, 式 (10) 中の遷移行列 $\frac{\partial \boldsymbol{x}_{t_{f}}}{\partial \boldsymbol{\lambda}_{t_{0}}}$ 解析的に得るのは極めて困難なので初期値 $\boldsymbol{\lambda}_{t_{0}}$ の各要素を微小 変位させたときの状態量 $\boldsymbol{x}_{t_{f}}$ の変化を数値的に求めて行列の 要素を近似する.

（2）動作時間が自由の場合

基本的な解法手順は（1）の場合と同一であるが, 動作時間 $t_{f}$ におけるハミルトン関数 $H_{t_{f}}$ の值に次の条件が付加される.

$$
H_{t_{f}}=0
$$

したがって, 動作終了時点での状態量 $\boldsymbol{x}_{t_{f}}$ と式 (11) が制約 条件となるので式（10）は次のように変更される.

$$
\begin{aligned}
{\left[\begin{array}{c}
\boldsymbol{\lambda}_{t_{0}}^{\text {new }} \\
t_{f}^{\text {new }}
\end{array}\right]=} & {\left[\begin{array}{l}
\boldsymbol{\lambda}_{t_{0}}^{\text {old }} \\
t_{f}^{\text {old }}
\end{array}\right]-\varepsilon\left[\begin{array}{ll}
\frac{\partial \boldsymbol{x}_{t_{f}}}{\partial \boldsymbol{\lambda}_{t_{0}}} & \frac{\partial \boldsymbol{x}_{t_{f}}}{\partial t_{f}} \\
\frac{\partial H_{t_{f}}}{\partial \boldsymbol{\lambda}_{t_{0}}} & \frac{\partial H_{t_{f}}}{\partial t_{f}}
\end{array}\right]^{-1} } \\
& \times\left(\left[\begin{array}{c}
\boldsymbol{x}_{t_{f}} \\
H_{t_{f}}
\end{array}\right]-\left[\begin{array}{c}
\boldsymbol{x}\left(t_{f}\right) \\
0
\end{array}\right]\right)
\end{aligned}
$$

結局, 式 (12) を用いて, 初期値 $\boldsymbol{\lambda}_{t_{0}}$ と動作時間 $t_{f}$ を適宜 変化させて (1) と同様な手法で $x_{t_{f}}$ が $\boldsymbol{x}\left(t_{f}\right)$ と一致し, かつ 式（11）を満足する最適軌道を求める.

\section{3. シミュレーション結果と考察}

3.1 シミュレーションモデル

Fig. 1 に示す 2 自由度の垂直型マニピュレータに本研究で提 案する軌道計画手法を適用する. 図で, $\theta$ は回転角, $m$ は質量, $I$ は重心回りの慣性モーメント, $l$ はリンク長さ, $l c$ は関節か らリンク重心までの距離, そして添字の 1,2 および 3 はそれぞ れリンクの 1 と 2 およびハンドを表す. 解析に用いたマニピュ レータと滅速機を含む関節駆動モータの諸元を Table 1 に示 す.このモデルの運動方程式は, $\boldsymbol{\theta}=\left(\theta_{1}, \theta_{2}\right)^{T}, \boldsymbol{u}=\left(u_{1}, u_{2}\right)^{T}$ とすると次式で与えれる.

$$
\left[\begin{array}{ll}
m_{11} & m_{12} \\
m_{21} & m_{22}
\end{array}\right] \ddot{\boldsymbol{\theta}}+\left[\begin{array}{l}
h_{1} \\
h_{2}
\end{array}\right]+\left[\begin{array}{l}
g_{1} \\
g_{2}
\end{array}\right]+\boldsymbol{C} \dot{\boldsymbol{\theta}}=\boldsymbol{u}
$$

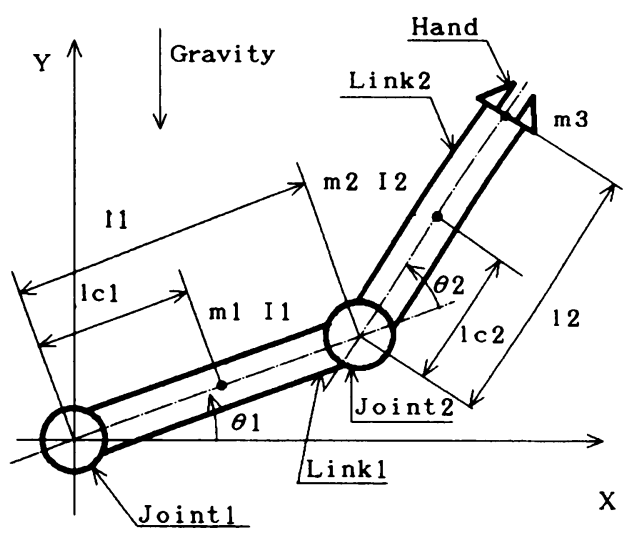

Fig. 1 Simulation model
ここで,

$$
\begin{aligned}
m_{11}= & m_{1} l_{c 1}^{2}+m_{2}\left(l_{1}^{2}+l_{c 2}^{2}\right)+m_{3}\left(l_{1}^{2}+l_{2}^{2}\right)+I_{1}+I_{2} \\
& +2\left(m_{2} l_{1} l_{c 2}+m_{3} l_{1} l_{2}\right) \cos \theta_{2} \\
m_{12}= & m_{2} l_{c 2}^{2}+m_{3} l_{2}^{2}+I_{2}+\left(m_{2} l_{1} l_{c 2}+m_{3} l_{1} l_{2}\right) \cos \theta_{2} \\
m_{21}= & m_{12} \\
m_{22}= & m_{2} l_{c 2}^{2}+m_{3} l_{2}^{2}+I_{2}
\end{aligned}
$$

また，

$\left[\begin{array}{l}h_{1} \\ h_{2}\end{array}\right]$

$=\left[\begin{array}{l}-2\left(m_{2} l_{1} l_{c 2}+m_{3} l_{1} l_{2}\right) \dot{\theta_{1}} \dot{\theta_{2}} \sin \theta_{2}-\left(m_{2} l_{1} l_{c 2}+m_{3} l_{1} l_{2}\right) \dot{\theta}_{2}^{2} \sin \theta_{2} \\ \left(m_{2} l_{1} l_{c 2}+m_{3} l_{1} l_{2}\right) \dot{\theta}_{1}^{2} \sin \theta_{2}\end{array}\right]$

$\left[\begin{array}{l}g_{1} \\ g_{2}\end{array}\right]$

$=\left[\begin{array}{l}\left(m_{1} l_{c 1}+m_{2} l_{1}+m_{3} l_{1}\right) g \cos \theta_{1}+\left(m_{2} l_{c 2}+m_{3} l_{2}\right) g \cos \left(\theta_{1}+\theta_{2}\right) \\ \left(m_{2} l_{c 2}+m_{3} l_{2}\right) g \cos \left(\theta_{1}+\theta_{2}\right)\end{array}\right]$

$\boldsymbol{C}=\operatorname{diag}\left(c_{1}, c_{2}\right)$

である、また, $x=\left(x_{1}, x_{2}, x_{3}, x_{4}\right)^{T}=\left(x_{p}^{T}, x_{v}^{T}\right)^{T}=\left(\theta^{T}, \dot{\theta}^{T}\right)^{T}$

\begin{tabular}{|c|c|c|}
\hline & Link1 & Link2 \\
\hline Length of Link & 0.3 & 0.4 \\
\hline $\begin{array}{l}\text { Distance From joint } \\
\text { to center of gravity }\end{array}$ & 0.15 & 0.2 \\
\hline Mass of link & 25 & 20 \\
\hline Mass of hand & & 2 \\
\hline Moment of inertia & 0.8 & 0.5 \\
\hline & Joint1 & Joint2 \\
\hline $\begin{array}{l}\text { Viscous damping c[Nms/rad] } \\
\text { coefficient }\end{array}$ & 0.2 & 0.1 \\
\hline Torque limit of motor & \pm 2.5 & \pm 1.0 \\
\hline $\begin{array}{l}\text { Torque constant } \quad \mathbf{k}[\mathrm{Nm} / \mathrm{A}] \\
\text { of motor }\end{array}$ & 0.6 & 0.3 \\
\hline Resistance of motor & 2 & 2 \\
\hline Gear ratio & $1 / 120$ & $1 / 120$ \\
\hline
\end{tabular}
とすると評価関数は,

$$
\begin{aligned}
\boldsymbol{J}= & \int_{t_{0}}^{t_{f}}\left(\boldsymbol{u}^{T}\left[\begin{array}{cc}
\frac{r_{1} p_{1}^{2}}{k_{1}^{2}} & 0 \\
0 & \frac{r_{2} p_{2}^{2}}{k_{2}^{2}}
\end{array}\right] \boldsymbol{u}\right. \\
& \left.+\boldsymbol{x}_{v}^{T}\left[\begin{array}{cc}
c_{1} & 0 \\
0 & c_{2}
\end{array}\right] \boldsymbol{x}_{v}\right) d t
\end{aligned}
$$

となる. 次に, 随伴変数 $\boldsymbol{\lambda}=\left(\lambda_{1}, \lambda_{2}, \lambda_{3}, \lambda_{4}\right)^{T}$ を用いてハミル トン関数を定義し最適入力を求める.このモデルの最適入力は,

$$
u_{i}= \begin{cases}\frac{\tau_{i \min }}{p_{i}}, & u_{c i}<\frac{\tau_{i \min }}{p_{i}} \\ u_{c i}, & \frac{\tau_{i \min }}{p_{i}} \leq u_{c i} \leq \frac{\tau_{i \max }}{p_{i}} \quad(i=1,2) \\ \frac{\tau_{i \max }}{p_{i}}, & \frac{\tau_{i \max }}{p_{i}}<u_{c i}\end{cases}
$$

Table 1 Parameters of a manipulator 


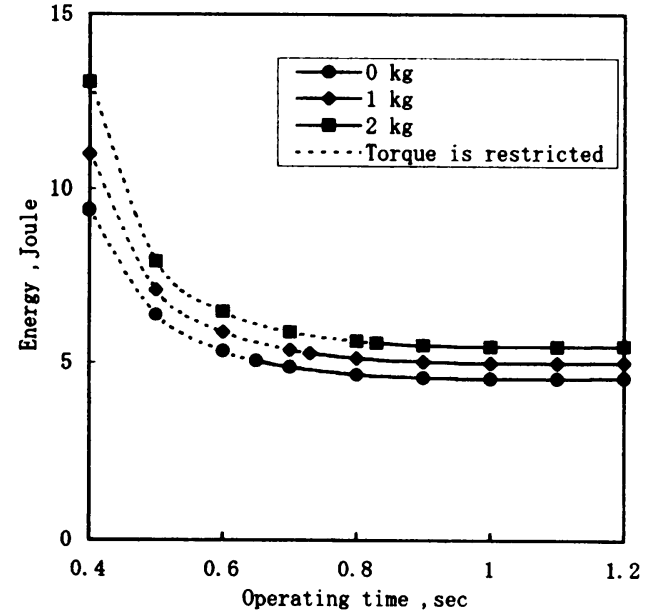

Fig. 2 Dissipated energy (Movement 1)

となる.このとき，

$$
\begin{aligned}
& u_{c 1}=\frac{-\lambda_{3} a_{3}+\lambda_{4}\left(a_{3}+a_{2} \cos x_{2}\right)}{2 w_{1}\left(\left(a_{1}+2 a_{2} \cos x_{2}\right) a_{3}-\left(a_{3}+a_{2} \cos x_{2}\right)^{2}\right)} \\
& u_{c 2}=\frac{\lambda_{3}\left(a_{3}+a_{2} \cos x_{2}\right)-\lambda_{4}\left(a_{1}+2 a_{2} \cos x_{2}\right)}{2 w_{2}\left(\left(a_{1}+2 a_{2} \cos x_{2}\right) a_{3}-\left(a_{3}+a_{2} \cos x_{2}\right)^{2}\right)}
\end{aligned}
$$

ここで,

$$
\begin{aligned}
& a_{1}=m_{1} l_{c 1}^{2}+m_{2}\left(l_{1}^{2}+l_{c 2}^{2}\right)+m_{3}\left(l_{1}^{2}+l_{2}^{2}\right)+I_{1}+I_{2} \\
& a_{2}=m_{2} l_{1} l_{c 2}+m_{3} l_{1} l_{2} \\
& a_{3}=m_{2} l_{c 2}^{2}+m_{3} l_{2}^{2}+I_{2} \\
& w_{i}=\frac{r_{i} p_{i}^{2}}{k_{i}^{2}} \quad(i=1,2)
\end{aligned}
$$

である。この入力のもとで式（8）と式（9）に相当するそれぞ れ 4 個の微分方程式を動作前後での条件を満足するように解く ことで最適軌道が得られる。

\section{2 動作時間と消費エネルギー}

動作条件を，

動作 1 初期姿勢 $\left(\theta_{1}=-90^{\circ}, \theta_{2}=90^{\circ}\right)$ および

$$
\text { 目標姿勢 }\left(\theta_{1}=0^{\circ}, \theta_{2}=90^{\circ}\right)
$$

動作 2 初期姿勢 $\left(\theta_{1}=0^{\circ}, \theta_{2}=0^{\circ}\right)$ および

$$
\text { 目標姿勢 }\left(\theta_{1}=0^{\circ}, \theta_{2}=90^{\circ}\right)
$$

と設定し、ハンドの保持質量を $0,1.0$ および $2.0[\mathrm{~kg}]$ としたと きの動作時間とその動作時間における最適軌道での消費エネル ギーを Fig. 2 と Fig. 3 に示す.なお，図の点線は軌道の生成 過程においてトルクの制約を受けていることを示す．動作 1 で はこの領域は短い動作時間に限られているが，動作 2 では広い 領域でトルクが拘束されいる。この領域は保持質量の増加に伴 い大きく增加しており，最適軌道の生成においてトルクの制約 を考虑するのは重要な要素であることが分かる，動作時間と消 費エネルギーの関係は保持質量に依存せず同一であり, 消費エ ネルギーは短い動作時間では時間の増加に伴い急激に減少する が，次第に变化がゆるやかになりほほ一定の值となる。このこ とは消費エネルギーを制御規範とする軌道計画では消費エネル ギーが大きく変化する領域を避けて動作時間を設定する必要が

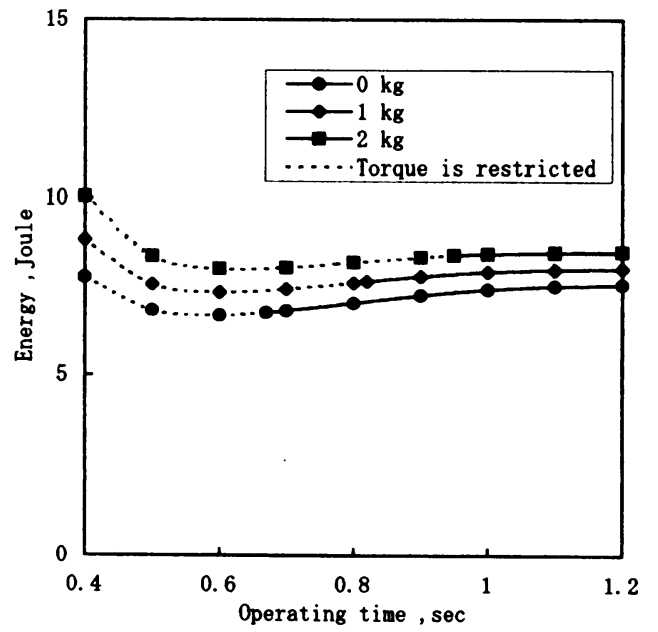

Fig. 3 Dissipated energy (Movement 2)

Table 2 Optimal operation time and dissipated energy

\begin{tabular}{|c|c|c|c|c|}
\hline \multirow{2}{*}{$\begin{array}{l}\text { Holding } \\
\text { mass[kg] }\end{array}$} & \multicolumn{2}{|c|}{ Movement 1 } & \multicolumn{2}{c|}{ Movement 2 } \\
\cline { 2 - 5 } & $\begin{array}{l}\text { Optimal } \\
\text { operating } \\
\text { time[sec] }\end{array}$ & $\begin{array}{l}\text { Dissipated } \\
\text { energy } \\
\text { [Joule] }\end{array}$ & $\begin{array}{l}\text { Optimal } \\
\text { operating } \\
\text { time[sec] }\end{array}$ & $\begin{array}{l}\text { Dissipated } \\
\text { energy } \\
\text { [Joule] }\end{array}$ \\
\hline 0 & 1.03 & 4.55 & 0.58 & 6.71 \\
\hline 1 & 1.03 & 4.99 & 0.61 & 7.38 \\
\hline 2 & 1.03 & 5.47 & 0.63 & 8.05 \\
\hline
\end{tabular}

あることを示している. 次に, 動作時間を自由とした条件のも とで式（12）を用い最適軌道を求め, 最適動作時間とそのとき の消費エネルギーを Table 2 に，ハンドの保持質量が $0[\mathrm{~kg}]$ のときの最適軌道を Fig. 4 と Fig. 5 に示す. 動作 1 と 2 の最 適動作時間は消費エネルギーが急激に変化した後, 長い時間を 経ずして現れている。これは動作時間を自由とした条件での軌 道計画手法を用いることで消費エネルギーが大きく変化しない 領域のなかで比較的短い動作時間での軌道の生成が可能なこと を示している．また，最適軌道に関しては動作 1 と 2 のいずれ も単関節で移動が可能であるにもかかわらず二つの関節が互い に協調して動作し（Fig. 4 と Fig. 5 の (c))，ハンドは重力に抗 するトルクが少ない経路を移動しているのが分かる（Fig. 4 と Fig. 5 の (a)).

\section{3 動作時間を考慮した最適軌道の特性}

動作条件を，

動作 1 初期姿勢 $\left(\theta_{1}=-90^{\circ}, \theta_{2}=90^{\circ}\right)$ および目標姿勢 $\left(\theta_{1}\right.$ は $-90^{\circ}<\theta_{1}<0^{\circ}$ の範囲で設定, $\left.\theta_{2}=90^{\circ}\right)$

動作 2 初期姿勢 $\left(\theta_{1}=0^{\circ}, \theta_{2}=0^{\circ}\right)$ および目標姿势

$$
\left(\theta_{1}=0^{\circ}, \theta_{2} \text { は } 0^{\circ}<\theta_{2}<90^{\circ}\right. \text { の範囲で設定) }
$$

とし, 各目標姿勢に対する軌道と解析結果を Fig. 6 と Fig. 7 に示す。これらの図より動作条件の変化に伴う軌道の特性を次 のようにまとめることができる。

（1）動作 1 のハンドの経路は関節 1 の方向にふくらんだ孤を 描いているが移動距離の短縮に伴い始点と終点を結ぶ直線に近 づき，動作 2 ではすべての動作において直線に近い経路となっ ている. また，ハンドの速度のパターンは動作 1 の長い動作距 離の軌跡を除きほほ同一でありベル型となっている。 


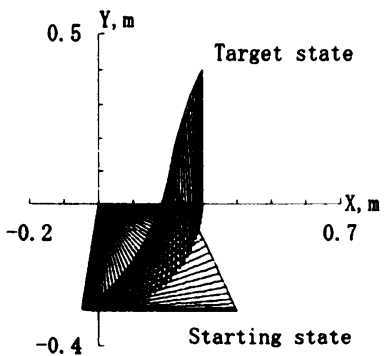

(a) Hand path

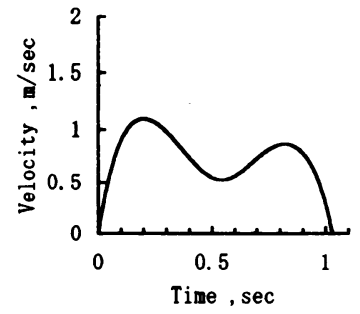

(c) Tip velocity

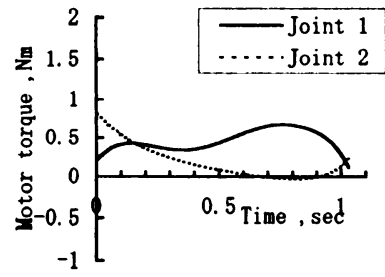

(b) Motor torque

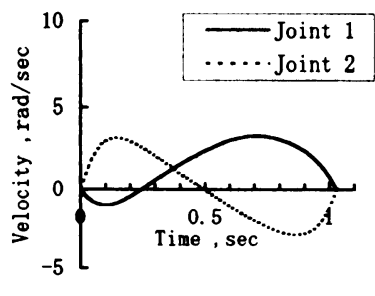

(d) Angular velocity

Fig. 4 Trajectory at optimal operation time (Movement 1)

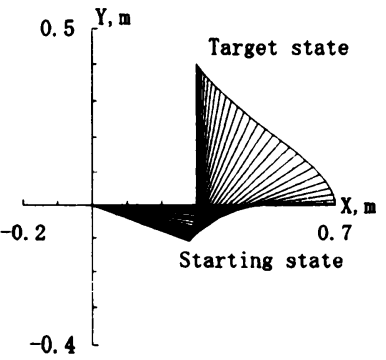

(a) Hand path

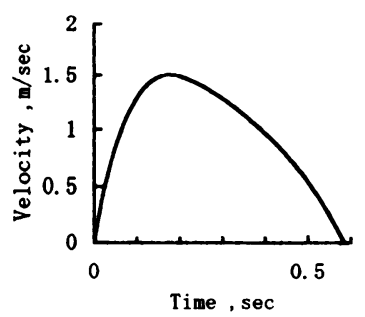

(c) Tip velocity

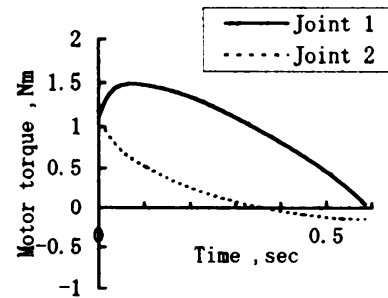

(b) Motor torque

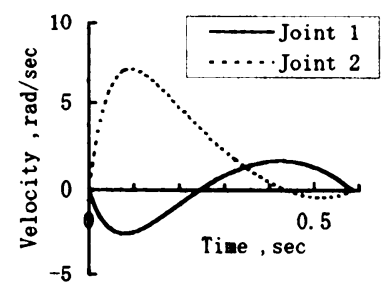

(d) Angular velocity

Fig. 5 Trajectory at optimal operation time (Movement 2)

（2）最適動作時間はいずれの動作でも移動距離の増加に伴 いほほ直線的に増加している。また，消費エネルギーの増加率 は移動距離が長くなるに従い減少している。これは特定の移動 距讙以上でジュール熱による散逸エネルギーがほほ一定となる 軌道が生成されていることによる効果であり消費エネルギーを 最少とする最適軌道の特徴であるとともに利点である.

\section{4. 最適軌道とヒトの生成する軌道}

最適軌道の基本的な特性の一つは二つの関節が互いに協調し て動作することである。これは同時にヒトが上肢運動において 随意的に生成する軌道の持つ特性と同様である.ヒトの運動軌

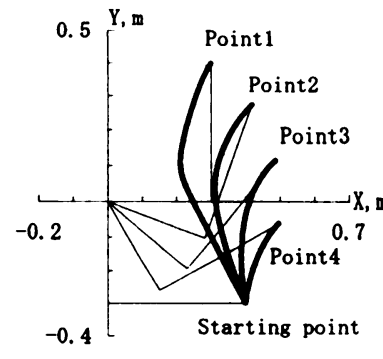

(a) Hand path

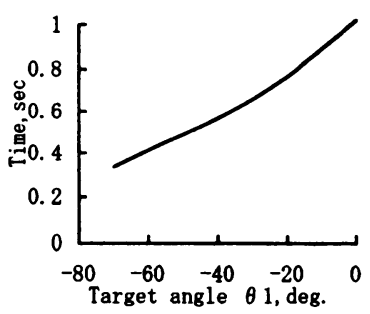

(d) Optimal operating time
Point $1\left(\theta_{1}=0^{\circ}\right)$

…P.Point $2\left(\theta 1=-20^{\circ}\right)$

-.- Point $3\left(\theta 1=-40^{\circ}\right)$

$-\cdots-\operatorname{Point} 4\left(\theta 1=-60^{\circ}\right)$

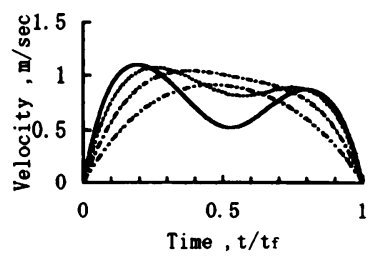

(b) Tip velocity

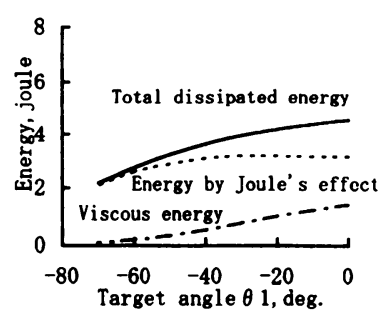

(c) Dissipated energy
Fig. 6 Trajectory and dissipated energy to distances of initial and target points (Movement 1)

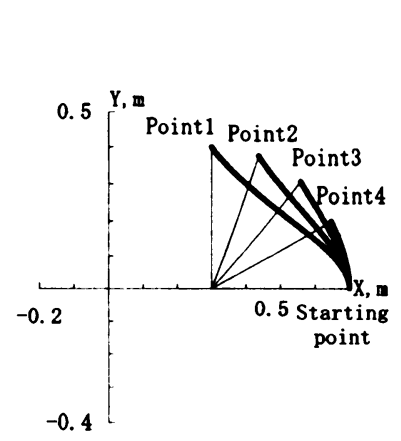

(a) Hand path

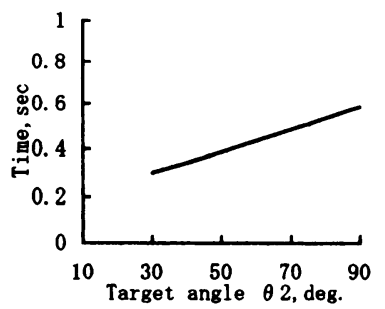

(c) Optimal operating time
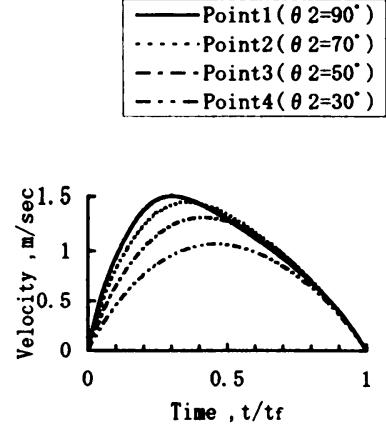

(b) Tip velocity

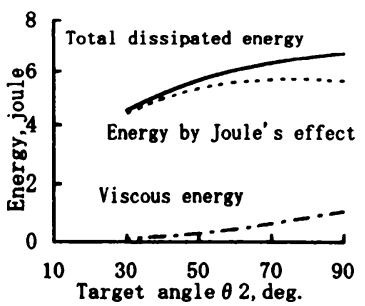

(d) Dissipated energy
Fig. 7 Trajectory and dissipated energy to distances of initial and target points (Movement 2)

道の具体的な特徴として，身体正面で手が任意の方向に自由に 動かせる姿勢からの動作では手は始点と終点を結ぶ直線に近い 経路を移動し手の速度はベル状に変化する [14][15]. また，腕 を伸ばした姿勢からの動作では手の速度はべル状に変化するが 経路はやや身体の外側に䐍らむ曲線となる [11][12]．このよう 


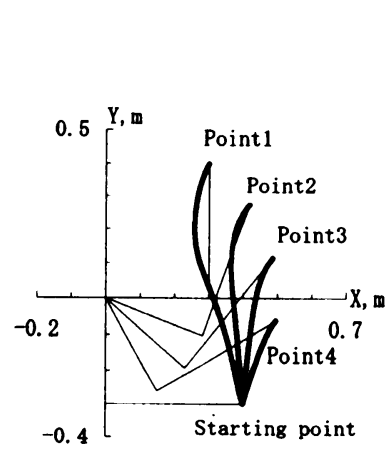

(a) Hand path
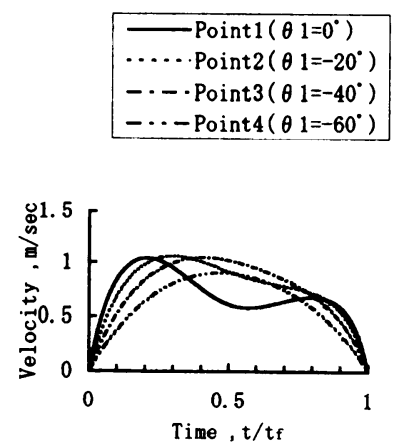

(b) Tip velocity
Fig. 8 Hand paths and tip velocities (Movement 1)

なとトの生成する軌道に関して, 山崎ら [16]は主たる運動の決 定要素は筋・関節の粘性抵抗と筋出力および筋力維持に要する 熱損失（消費エネルギー）であると指摘している．筆者らは局 と肘のエネルギー消費特性が同一としたとき，軌道によって変 化する消費エネルギーは，

$$
\boldsymbol{J}=\int_{t_{0}}^{t_{f}}\left(w_{1} \boldsymbol{u}^{T} \boldsymbol{u}+w_{2} \dot{\boldsymbol{x}}_{v}^{T} \dot{\boldsymbol{x}}_{v}\right) d t
$$

となることを示した [12]. なお， $\boldsymbol{u}=\left(u_{1}, u_{2}\right)^{T}$ は関節トルク， $\boldsymbol{x}_{v}=\left(\dot{\theta}_{1}, \dot{\theta}_{2}\right)^{T}$ は関節速度であり, 添え字の 1 と 2 はそれぞ れ局と肘を表す。 また， $w$ はヒトの上肢の生理的特性により決 定される定数である．式（16）に示すエネルギーの消費要素は 被積分項の定数を除き式 (14) と同一であり, ヒトはマニピュ レータと極めて類似したエネルギー消費特性をもっていること が分かる。

式（14）を用いて生成した軌道（Fig. 6 と Fig. 7) は移動距 離の限られた範囲ではハンドの経路は直線に近く速度はベル状 に変化している.しかし, 動作 1 でハンドの移動距離が大きい 動作では必ずしもヒトの軌道の特徴を示しておらず, これは評 価関数を構成する二つの消費エネルギー要素の重みがヒトとマ ニピュレータでは相違していることに起因すると考えられる。 ヒトの筋肉と関節の粘性により消費するエネルギーの割合はマ ニピュレータのものより大きいと考え, 運動モデルの動特性は そのままで, 式 (14) の評価関数の粘性係数を 2 倍とし, 見か け上粘性で多くのエネルギーを消費しているとして 3.3 節と同 一動作条件で最適軌道を生成した（Fig. 8 と Fig.9）. Fig.6 と Fig. 8 を比較すると,より広い動作範囲でハンドの経路は 直線に近づき，速度パターンはべル型に移行している。また， Fig. 7 と Fig. 9 からは，ハンドの速度パターンはいずれもべル 型であり，経路は身体の外側に膨らむ曲線へと変化しており， 腕が伸びた姿勢から動作するヒトの軌道の特徽を示しているの が分かる，次に，動作時間に関して軌道を評価すると，評価関 数の粘性係数を変えても最適動作時間はほとんど変化せず（最 大で 3\%)，Fig. 6 と Fig. 7 の (c) に示すように動作時間は増加 する. 結局, Fig. 8 と Fig. 9 は動作 1 の動作時間が長い軌道を 除き，動作 1 と 2 のいずれの場合もヒトと同一の特性を持つ軌 道であることが分かる。

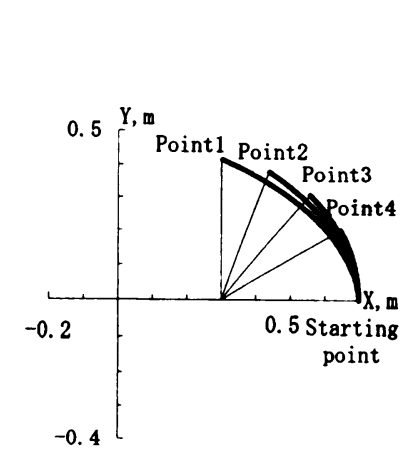

(a) Hand path
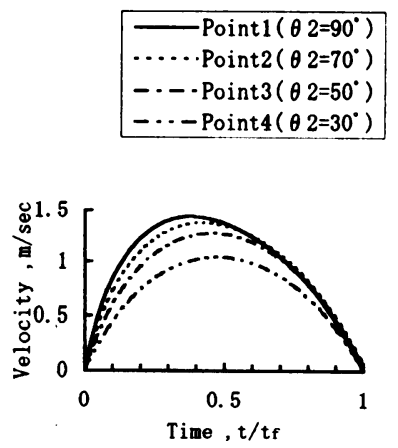

(b) Tip velocity
Fig. 9 Hand paths and tip velocities (Movement 2)

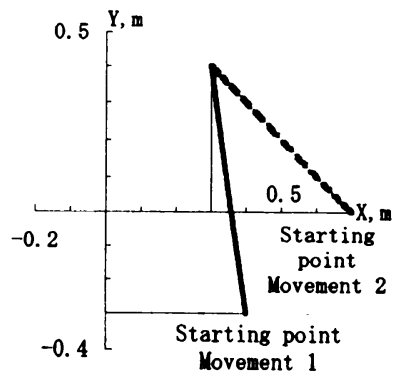

(a) Hand path

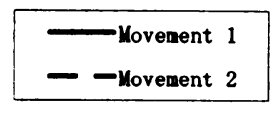

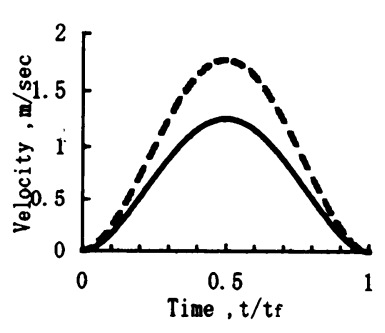

(b) Tip velocity
Fig. 10 Hand paths and tip velocities by minimum jerk criterion

一方，ヒトの運動軌道の生成に関して Flash と Hogan[10] は 評価関数を作業空間の手先位置 $(x, y)$ の躍動を用いて,

$$
\boldsymbol{J}=\frac{1}{2} \int_{t_{0}}^{t_{f}}\left[\left(\frac{d^{3} x}{d t^{3}}\right)^{2}+\left(\frac{d^{3} y}{d t^{3}}\right)^{2}\right] d t
$$

と定義した．動作 1 と 2 で関節が最も大きく変位し，動作時間 をエネルギー最少規範の軌道と同一とし生成した軌道を Fig10 に示す．図に示すように，この規範で生成される軌道は動作の 種類にかかわらず手の経路は直線で速度はべル状となるので, 動作 1 の軌道はヒトの運動軌道によく類似しているのが分かる. しかし，動作 2 ではヒトは身体の外側に膨らむ曲線経路を選択 するが, この軌道は必ずしもヒトの特徴を示していない. 結局, エネルギー最少規範と躍動最少規範の軌道を比較すると, 躍動 最少規範を用いることで動作開始姿勢の制限のなかで動作時間 の大小にかかわらずヒトに近い軌道を生成できる。一方，エネ ルギー最少規範の軌道は動作の種類にかかわらず比較的速い動 作のヒトの運動軌道と同一の特性を持つことが分かった.

$$
\text { 5. ま め }
$$

本研究では評価関数をマニピュレータが運動の過程で消費す るエネルギーで定義し，これを最少とする軌道を得るための定 式化と解法アルゴリズムを示した，次に，2 自由度の垂直型マ ニピュレータをシミュレーションモデルとして最適軌道の生成 
と解析を行った. その結果を用いて最適軌道の動作時間と消費 エネルギーの関係を求め, 動作時間を変数とする最適軌道を用 いることで消費エネルギーの最少化を実現するとともに動作時 間をも短縮する利点のあることを示した．また，ハンドの移動 距離を変化させることで移動距離と最適動作時間および消費工 ネルギーの関係さらに動作時間を考虑した最適軌道の特性を明 らかにした. 最後に, ヒトとマニピュレータは非常に類似した エネルギー消費特性を持ち, 同時に消費エネルギーを評価関数 とする軌道計画手法を用いることで比較的速い動作のヒトの随 意由運動における軌道を生成できることを示した。このことは, 本研究で提案する軌道計画手法が自然な制御感覚を持つ動力義 手の開発など産業用のみならず広範囲の分野で利用できる可能 性を示している.

\section{参 考 文 献}

[1] 山本, 尾崎, 毛利: “逐次改善によるマニピュレータの軌道計画”, 計 测自動制御学会論文集, vol.24, no.9, pp.942-947, 1988.

[2] 寺本, 小野, Ö. Turhan：“平均的発熱が制限となる運動機構の高 速駆動に関する研究（第 2 報， ロボットアームの軌道生成問題の解 法と 2 自由度系の解析例)”, 日本機械学会論文集, (C 編), vol.57, no.544, pp.3869-3876, 1991.

[3] M. Vukobratović and M. Kirćanski: "A Method for Optimal Synthesis of Manipulation Robot Trajectories," Trans. ASME, J. of DSMC, vol.104, pp.188-193, 1982.

[4] 尾崎, 山本, 毛利：“空間経路が指定されるマニピュレー夕動作軌道 計画”, 計測自動制御学会論文集, vol.23, no.3, pp.288-293, 1987.
[5] 鈴木, 永井, 大熊：“運動エネルギーに着目したマニピュレータの実 時間軌道計画法”, 日本ロボット学会誌, vol.10, no.2, pp.199-207, 1992.

[6] T. Kashima and N. Satoh: "Optimal Trajectory of Manipulators with a Weighted Joint Energy Criterion," Proc. of the ISMCR'93, pp.Cm.II, 7-12, 1993.

[7] 泉：“非線形摩擦をもつ水平多関節マニピュレー夕のPTP 制御に抒 ける消費エネルギー最少化”，日本ロボット学会誌，vol.13，no.8， pp.1179-1185, 1995.

[8] B. Kim and K. Shin: "Suboptimal Control of Industrial Manipulators with a Weighted Minimum Time-Fuel Criterion," Trans. on Automatic Control, vol.AC-30, no.1, pp.1-10, 1985.

[9] H. Greeting, L. Guzzella, S. Hepner and C. Onder: "TimeOptimal Motions of Robots in Assembly Tasks," Trans. on Automatic Control, vol.AC-31, no.6, pp.512-518, 1986.

[10] T. Flash and N. Hogan: "The Coordination of Arm Movements: An Experimentally Confirmed Mathematical Model," J. Neuroscience, vol.5, no.7, pp.1688-1703, 1985.

[11] Y. Uno, M. Kawato, and R. Suzuki: "Formation and Control of Optimal Trajectory in Human Multi-Joint Arm Movement," Biol. Cybern., no.61, pp.89-101, 1989.

[12] 加島, 石動： “ヒトの上肢運動における軌道制御”, 計測自動制御学 会論文集, vol.31, no.9, pp.1416-1422, 1995.

[13] A. Bryson, Jr. and Yu-Chi Ho: Applied Optimal Control, pp.215-217, Hemisphere Pub. Corp., 1975.

[14] P. Morasso: "Sapcial Control of Arm Movements," Experimental Brain Research, 42, pp.223-227, 1981.

[15] W. Abend, E. Bizzi, and P. Morasso: "Human Arm Trajectory Formation," Brain, 105, pp.331-348, 1982.

[16] バイオメカニズム学会編：バイオメカニズム 8, 山崎, 六馬：上肢運 動の決定要素, pp.27-36, 東京大学出版会, 1986.

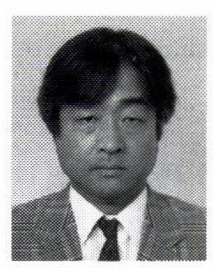

会員.
加島 正 (Tadashi Kashima)

1951 年 11 月 22 日生. 1975 年北海道大学工学部卒 業. 同年住友重機械工業（株）入社. 1982 1984 年ウィスコンシン大学大学院留学. 1988 年現北海 道職業能力開発短大教官を経て, 現在北海道大学 大学院工学研究科研究生. ロボット, システム制御 の研究に従事. ASME, 計測自動制御学会などの (日本ロボット学会正会員)

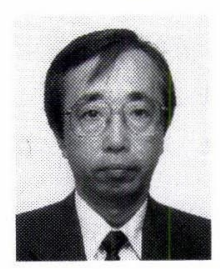

石動善久 (Yoshihisa Isurugi)

1949 年 2 月 10 日生. 1974 年北海道大学工学研究 科修士課程修了. 工学博士. 同年富士通 (株) 勤務. 1976 年北海道大学工学部精密工学科助手. 講師を 経て, 1987 年同助教授, 現在にいたる. 非線形制 御理論およびディジタル制御の研究に従事. 計測自 動制御学会, システム制御情報学会などの会員. 